\title{
Course Outcome-Program Outcome Mapping Matrix \& Attainment -Issues and Model Based Solutions for Tier II Category
}

\author{
Dr. L S Admuthe ${ }^{1}$, Deepali Yoginath Loni ${ }^{2}$ \\ ${ }^{1}$ Professor, Department of Electronics, D.K.T. E's Textile \& Engineering Institute, Ichalkaranji \\ ${ }^{2}$ Assistant ProfessorAuthor Department, D.K.T. E's Textile \& Engineering Institute, Ichalkaranji \\ ${ }^{1}$ lsadmuthe@gmail.com \\ 2deepaliloni@rediffmail.com
}

\begin{abstract}
One of the important element of Outcome Based Education(OBE) is establishment and attainment of Course Outcomes(COs) and Program Outcome(POs). POs are designed at program level considering knowledge and skills of the students and should demonstrate its attainment at the completion of course and program. COs are knowledge and skills that are formulated for each course. These COs are mapped to POs and attainment of each PO is calculated by various tools considering set target levels. Depending on target level achieved, action plan is decided at course level as well as program level for improvement if attainment level is weak. There are many difficulties in calculating attainment of COs and POs particularly in programs affiliated to university. In this paper two different models are developed for mapping and attainment of COs and POs. The results are tested for Electronics Engineering program affiliated to university. Major difficulty is in the attainment of course outcome due to university examination. The various issues in mapping and attainment are addressed in this paper with reference to June 2015 Self-Assessment Report.
\end{abstract}

Keywords: Outcome based education; Course outcome; Program outcome; Attainment

\section{Dr L S Admuthe}

Department of Electronics,D.K.T. E's Textile \&

Engineering Institute, Ichalkaranji

lsadmuthe@gmail.com

\section{Introduction}

In quality teaching and learning process, mapping and attainment is becoming an important process. The compliance of continuous improvement can be done by deciding action plan for weak attainment and is a key factor leading to continuous student learning.

The process of mapping and attainment of COs and POs is a complex and time consuming process. There are various issues related to university affiliated colleges. Issues are: Issue1: COs varies course-wise and program-wise. There is no standard procedure laid to calculate COs and POs. Due to different assessment methods, it is a difficult task to develop common attainment method. Issue2: University results plays major role in attainment of course. The problem associated with university results is that, university does not issue question wise marks of each student and in such a case individual course outcome attainment is not possible. Issue 3: Internal assessment is the requirement of continuous assessment and is essential for each $\mathrm{CO}$ attainment. University does not provide support for continuous assessment like test.

All these issues are addressed in this paper. Model based approach is developed for mapping and attainment at course level and program level considering both direct and indirect tools and target levels. Two models are proposed. In the first model there are two sub models. One is to test the weak mapping of POs with respect to course outcome at course level and second is to test weak mapping of POs considering all courses of the program at program level. Second model is attainment model consist of three sub models, one is used to find attainment by direct and indirect method at course level to find weak and unmapped COs. Second is to find weak POs due to COs attainment and third is to find weak POs considering all COs of the courses to take action at program level. Models are tested for Electronics Engineering course affiliated to university and results are taken for continuous improvement 


\section{Program Assessment Methodology}

The following steps are used to formulate course outcome, conduct mapping and attainment of course outcome and program outcomes.

- Detail study of program outcomes.

- Develop course outcomes for each of the courses in the curriculum.

- $\quad$ Create a mapping matrix between courses outcome and program outcomes, indicating which courses contribute to which program outcomes.

- $\quad$ Decide attainment tools used to assess the course and measure performance in terms of levels i.e 1-low, 2medium, 3-high. These levels indicate the extent to which a student achieves the course outcomes for each course.

- $\quad$ Calculate overall program outcome using the CO-PO mapping matrix.

This paper addresses mapping and attainment models as follows

- $\quad$ Model development for mapping of COs and POs.

- COs and POs mapping at course level

$\circ$ COs and POs mapping at program level

- Development of Attainment model

- COs attainment at course level

- POs attainment model at course level

- POs attainment model at program level

Flowcharts for above methodology are shown in Fig. 1 and Fig. 2.

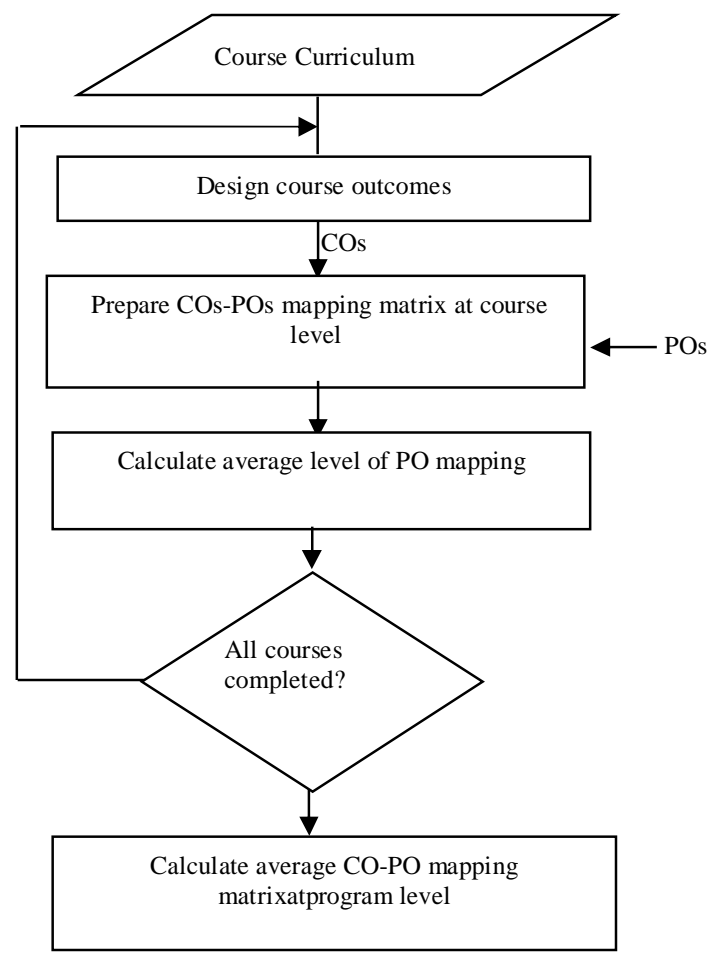

Fig. 1 Mapping of COs-POs mapping matrix

3. Model Development for Mapping of COs and POs at Course Level and Program Level

JeËr
A. COs and POs Mapping at Course Level

Course Outcomes assessment is the core assessment of the courses that particular program offers. It assesses directly the student learning experience as well as teaching effectiveness. Learning outcomes are nothing but the Course outcomes of that course and is prepared by faculty who is teaching that particular course. Mapping of course outcomes to program outcomes is done by examining curriculum and program outcomes. Mapping levels decide contribution of course to achieve program outcome. To illustrate mapping an example of Digital Signal Processing (DSP) subject is taken into consideration. Table1 shows DSP course outcomes mapped to program outcomes.

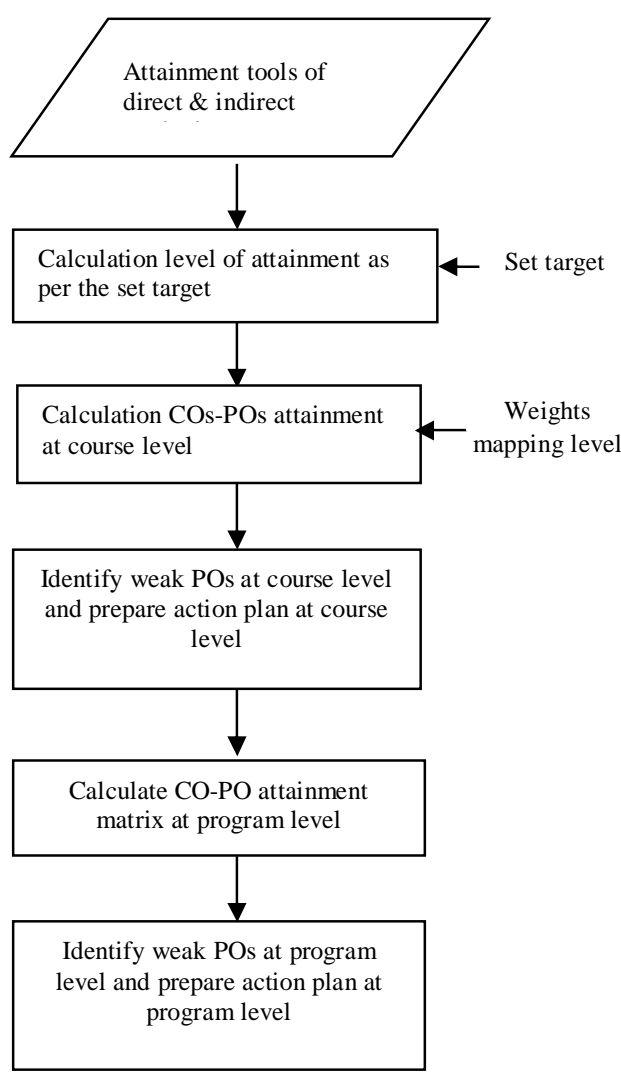

Fig.2 Attainment of COs-POs

Table 1. COs - POs Mapping matrix for DSP course (1-low, 2medium, 3-high)

Mapping of $\mathrm{CO}$ and $\mathrm{PO}$

\begin{tabular}{|c|c|c|c|c|c|c|c|c|c|c|c|c|}
\hline \multicolumn{13}{|c|}{ Mapping of $\mathrm{CO}$ and $\mathrm{PO}$} \\
\hline PO & $\begin{array}{l}P \\
0 \\
1\end{array}$ & $\begin{array}{l}P \\
0 \\
2\end{array}$ & $\begin{array}{l}P \\
0 \\
3\end{array}$ & $\begin{array}{l}P \\
0 \\
4\end{array}$ & $\begin{array}{l}P \\
0 \\
5\end{array}$ & $\begin{array}{l}P \\
0 \\
6\end{array}$ & $\begin{array}{l}P \\
0 \\
7\end{array}$ & $\begin{array}{l}P \\
0 \\
8\end{array}$ & $\begin{array}{l}P \\
0 \\
9\end{array}$ & $\begin{array}{l}P \\
0 \\
1 \\
0\end{array}$ & $\begin{array}{r}P \\
0 \\
11\end{array}$ & $\begin{array}{l}P \\
0 \\
12\end{array}$ \\
\hline \multicolumn{13}{|c|}{$\mathrm{CO}\rangle$} \\
\hline $\begin{array}{l}\text { C3 } \\
10 . \\
1\end{array}$ & 3 & - & - & - & - & - & - & - & - & - & - & - \\
\hline $\begin{array}{l}\text { C3 } \\
10 . \\
2\end{array}$ & 3 & 3 & 3 & - & - & - & - & - & - & - & - & - \\
\hline $\begin{array}{l}\text { C3 } \\
10 . \\
3\end{array}$ & 3 & - & 3 & 3 & - & - & - & - & - & - & - & - \\
\hline $\mathrm{C} 3$ & 3 & 1 & - & - & - & 3 & - & - & - & - & - & - \\
\hline
\end{tabular}




\begin{tabular}{|l|l|l|l|l|l|l|l|l|l|l|l|l|}
\hline $\begin{array}{l}10 . \\
4\end{array}$ & & & & & & & & & & & & \\
\hline $\begin{array}{l}\text { C3 } \\
10 . \\
5\end{array}$ & 2 & - & - & - & 1 & - & - & - & - & - & - & 1 \\
\hline $\begin{array}{l}\text { C3 } \\
10 . \\
6\end{array}$ & - & - & - & - & - & - & - & 1 & 3 & 2 & 1 & \\
\hline
\end{tabular}

Major issue in this mapping model is that if number of course outcome change or mapping level changes, then there is need to recalculate the change there upon happening in the Program Outcomes. This issue is addressed by designing a universal model as shown in Fig 3. This model is useful to find weak POs at course level irrespective of number of outcomes and mapping levels. Action plan can now be prepared for weakly mapped POs at course level.

The program outcomes obtained using the Model 1 is presented in Table 2. The result of Model 1 helps to identify weak POs at course level and accordingly assists the course instructor to prepare the action plan to bridge the gap between the curriculum and program outcomes.

$$
\frac{1}{N_{T C O C}} \sum_{i=1}^{\mathrm{NTCOc}}\left[X_{i} * W\right]
$$

NTCOc $=$ Total Number of Course Outcome for DSP $=6$

$\mathrm{Xi}=$ Mapping level 1,2 or 3 as per the Table 1

$\mathrm{W}=$ Weight assigned to mapping level (1/number of levels)

POi $=$ Program Outcome $\mathrm{i}$ (where $\mathrm{i}=1$ to 12 )

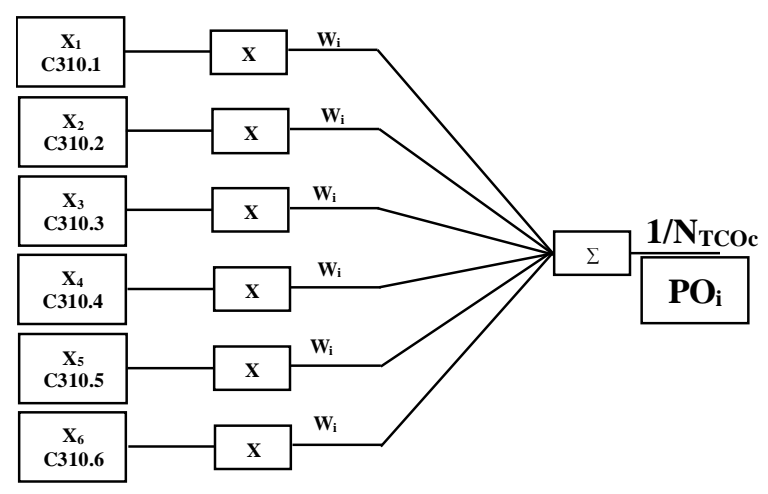

Fig. 3 Model 1: Measuring Program Outcomes of DSP course from its Course outcomes.

Table 2. Normalized Program Outcomes of DSP course using Model 1

\begin{tabular}{|c|c|c|c|c|c|c|c|c|c|c|c|c|}
\hline \multicolumn{13}{|c|}{ Overall PO mapping of DSP course } \\
\hline POD & $\begin{array}{l}\mathbf{P} \\
\mathbf{O} \\
1\end{array}$ & $\begin{array}{l}\mathbf{P} \\
\mathbf{O} \\
2\end{array}$ & $\begin{array}{l}\mathbf{P} \\
\mathbf{O} \\
\mathbf{3}\end{array}$ & $\begin{array}{l}P \\
\mathbf{O} \\
4\end{array}$ & $\begin{array}{l}\text { P } \\
\text { O } \\
5\end{array}$ & $\begin{array}{l}\mathbf{P} \\
\mathbf{O} \\
6\end{array}$ & $\begin{array}{l}\mathbf{P} \\
\mathbf{O} \\
7\end{array}$ & $\begin{array}{l}\mathbf{P} \\
\mathbf{O} \\
\mathbf{8}\end{array}$ & $\begin{array}{l}\mathbf{P} \\
\mathbf{O} \\
\mathbf{9}\end{array}$ & $\begin{array}{l}\mathbf{P} \\
\mathbf{O} \\
\mathbf{1} \\
\mathbf{0}\end{array}$ & $\begin{array}{l}\mathbf{P} \\
\mathbf{O} \\
\mathbf{1} \\
\mathbf{1}\end{array}$ & $\begin{array}{l}\mathbf{P} \\
\mathbf{O} \\
\mathbf{1} \\
2\end{array}$ \\
\hline $\begin{array}{l}\text { C31 } \\
0 \\
\text { (All } \\
\text { outc } \\
\text { ome } \\
\text { s) }\end{array}$ & $\begin{array}{l}0 . \\
7 \\
7\end{array}$ & $\begin{array}{l}0 . \\
2 \\
2\end{array}$ & $\begin{array}{l}0 \\
.3 \\
3\end{array}$ & $\begin{array}{l}0 . \\
1 \\
6\end{array}$ & $\begin{array}{l}0 . \\
0 \\
5\end{array}$ & $\begin{array}{l}0 . \\
1 \\
6\end{array}$ & - & $\begin{array}{l}0 . \\
0 \\
5\end{array}$ & $\begin{array}{l}0 . \\
1 \\
6\end{array}$ & $\begin{array}{l}0 . \\
1 \\
1\end{array}$ & $\begin{array}{l}0 . \\
1 \\
1\end{array}$ & $\begin{array}{l}0 . \\
1 \\
1\end{array}$ \\
\hline
\end{tabular}

\section{B. COs and POs Mapping at Program Level}

Issue- The $\mathrm{CO}$ - PO mapping matrix considering all courses together does not specifically pin points to the course and course outcomes which are the major contributors in making the POs weak. It is essential to identify the responsible course outcomes from the set of these courses and then properly plan the action. This will then in essence completes the feedback process of weak PO identification.

The solution is to create a $\mathrm{CO}-\mathrm{PO}$ mapping matrix considering individual course outcomes of all courses. The solution is proposed in Model 2 as shown in Fig. 4.

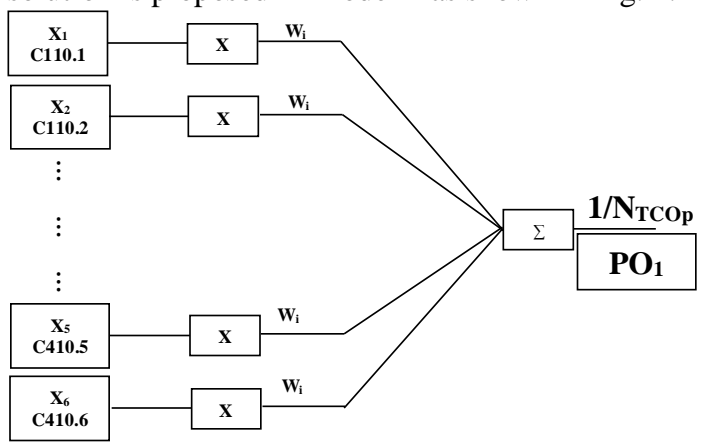

Fig.4 Model 2: Measuring Program Outcomes from all courses.

$$
\frac{1}{N_{T C O p}} \sum_{i=1}^{\mathrm{NTCOp}}\left[X_{i} * W\right]
$$

NTCOp $=$ Total Number of Course Outcome of all courses $\mathrm{Xi}=$ Mapping level 1, 2 or 3 as per the Table 1

$\mathrm{W}=$ Wight assign to mapping level

Table 3 shows result of Model 2 at program level taking all course outcomes of all courses. This model is useful to find weak POs at program level and prepare action plan either at course level or program level.

Table 3.Normalized Program Outcomes of all courses at program level using model 2.

\begin{tabular}{|c|c|c|c|c|c|c|c|c|c|c|c|c|}
\hline \multicolumn{13}{|c|}{ Overall PO mapping of DSP course } \\
\hline POD & $\begin{array}{l}\mathbf{P} \\
\mathbf{O} \\
1\end{array}$ & $\begin{array}{l}\mathbf{P} \\
\mathbf{O} \\
\mathbf{2}\end{array}$ & $\begin{array}{l}\mathbf{P} \\
\mathbf{O} \\
\mathbf{3}\end{array}$ & $\begin{array}{l}P \\
O \\
4\end{array}$ & $\begin{array}{l}\mathbf{P} \\
\mathbf{O} \\
\mathbf{5}\end{array}$ & $\begin{array}{l}\mathbf{P} \\
\mathbf{O} \\
6\end{array}$ & $\begin{array}{l}\mathbf{P} \\
\mathbf{O} \\
7\end{array}$ & $\begin{array}{l}\mathbf{P} \\
\mathbf{O} \\
8\end{array}$ & $\begin{array}{l}\mathbf{P} \\
\mathbf{O} \\
\mathbf{9}\end{array}$ & $\begin{array}{c}\mathbf{P} \\
\mathbf{O} \\
\mathbf{1 0}\end{array}$ & $\begin{array}{l}\mathbf{P} \\
\mathbf{O} \\
\mathbf{1 1}\end{array}$ & \begin{tabular}{|c}
$\mathbf{P}$ \\
$\mathbf{O}$ \\
$\mathbf{1 2}$
\end{tabular} \\
\hline $\begin{array}{l}\text { Consi } \\
\text { derin } \\
\text { g } \\
\text { cours } \\
\text { e } \\
\text { outco } \\
\text { mes } \\
\text { of all } \\
\text { cours } \\
\text { es }\end{array}$ & $\begin{array}{l}0 . \\
5\end{array}$ & $\begin{array}{l}0 . \\
3\end{array}$ & $\begin{array}{l}0 . \\
1\end{array}$ & $\begin{array}{l}0 . \\
3\end{array}$ & $\begin{array}{l}0 . \\
1\end{array}$ & $\begin{array}{l}0 . \\
1\end{array}$ & $\begin{array}{l}0 . \\
1\end{array}$ & $\begin{array}{l}0 . \\
1\end{array}$ & $\dot{1}$ & 1 & $\dot{1}$ & $\begin{array}{l}0 \\
. \\
1\end{array}$ \\
\hline
\end{tabular}

Overall PO mapping of DSP course

\section{Assessment Tools, Target Levels and Attainment of Course Outcome and Program Outcome}

To measure the attainment of each of the course outcomes, appropriate measurement tools, and corresponding targets 
are developed. This process implemented to measure the Program outcome is carried out in three steps

- Decide attainment tools and set target levels for each

- $\quad$ Find the attainment levels of each assessment tool with respect to set target levels

- $\quad$ Apply the model to find: 1. CO attainment at course level. 2. POs attainment at course level 3. POs attainment at program level.

\section{A. Setting Course Outcome Targets}

Issue number 3 is continuous assessment process. University curriculum does not support evaluation of students for internal assessment tool like test or assignment. Program has built a strong process for internal assessment and its implementation. The Table 4 shows tools used to measure the attainments of course learning outcomes, Weightage for attainment and also the assessment cycle.

Table 4.Assessment tools and its Weightage for course attainment

\begin{tabular}{|r|l|l|l|}
\hline Method & \multicolumn{1}{|c|}{$\begin{array}{c}\text { Tools for } \\
\text { Assessment }\end{array}$} & $\begin{array}{c}\text { \% } \\
\text { contribut } \\
\text { ion }\end{array}$ & $\begin{array}{l}\text { Assessment } \\
\text { Cycle }\end{array}$ \\
\hline Direct & University results & 0.8 & \\
\hline Direct & Internal class Tests & \multirow{2}{*}{0.2} & $\begin{array}{l}\text { Two class } \\
\text { tests per } \\
\text { semester }\end{array}$ \\
\cline { 2 - 2 } Direct & $\begin{array}{l}\text { Assignments/Tutori } \\
\text { al }\end{array}$ & $\begin{array}{l}\text { Assignments } \\
\text { (as applicable) }\end{array}$ \\
Direct & Practical evaluation & $\begin{array}{l}\text { Every } \\
\text { practical batch } \\
\text { per practical } \\
\text { per student }\end{array}$ \\
\cline { 2 - 2 } Direct & $\begin{array}{l}\text { Seminar/project } \\
\text { evaluation }\end{array}$ & $\begin{array}{l}\text { Once per } \\
\text { semester }\end{array}$ \\
\hline Indirect & Course Exit Survey & 0.2 & $\begin{array}{l}\text { At the end of } \\
\text { Semester }\end{array}$ \\
\hline
\end{tabular}

Implementation steps are as follows.

Step1: Tools used for course assessment are Direct Assessment Tools and Indirect Assessment Tools. The Weightage of these assessment tools in the overall course assessment is shown in Table IV

Step2- Set target levels: To set the target level average mark criteria is used. Using the guideline of June 2015 SAR, attainment levels of course outcomes are set as follows:

- $\quad$ Attainment Level 1: 60\% students scoring more than average test mark

- $\quad$ Attainment Level 2: $70 \%$ students scoring more than average test mark

- $\quad$ Attainment Level 3: 80\% students scoring more than average test mark

B. Development of Model for Computing Attainment of Course Outcome and Program Outcome

This is carried out in three different way

- COs attainment at course level

- $\quad$ POs attainment at course level

JeÈ.F
- $\quad$ POs attainment at program level.

1) COs attainment at Course Level:

a) Course Assessment through Internal Tools:Course attainment at course level is important part of OBE. It immediately reveals the weakly attained COs and assists the course instructor to prepare the action plan time to time during course teaching.

Fig 5 shows course outcome attainment model from internal assessment tools. As an example DSP course attainment model is prepared.

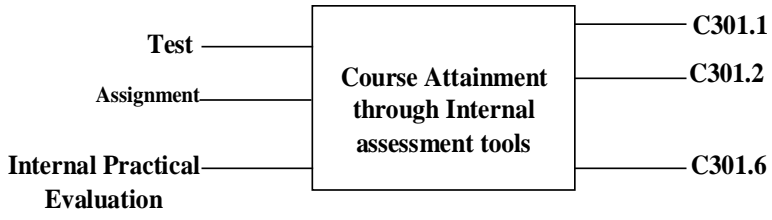

Fig. 5 Attainment of course outcome through internal assessment.

Attainment process of all assessment tools are same. Detail attainment process is explained by taking example of internal test results of DSP course. Distribution of test marks w.r.t course outcomes addressed by the test questions is shown in Table 5.

Table 5. Test marks of DSP in percentage

\begin{tabular}{|c|c|c|}
\hline $\begin{array}{c}\text { Course } \\
\text { outcomes }\end{array}$ & \%MARKS & Attainment levels \\
\hline C310.1 & 64 & 1.00 \\
\hline C310.2 & 55 & 0.00 \\
\hline C310.3 & 71 & 2.00 \\
\hline C310.4 & 62 & 1.00 \\
\hline C310.5 & - & \\
\hline C310.6 & - & \\
\hline
\end{tabular}

Similar table is prepared for all other internal assessment tools.

b) Course Assessment of University Examination: IssuesMajor difficulty is attainment of course outcomes from university result because university does not provide question wise marks distribution. There are two solutions

- Take the same attainment for all course outcomes. For example, if student scores $70 \%$ marks then attainment of all course outcomes is same i.e. $70 \%$ (Ref. June 2015 SAR guideline).

- $\quad$ The other proposed method presented in this paper is prediction of attainment of university course outcomes using the data of attainment of course outcomes through internal assessment tools. Fig 6 shows the model for predicting the course outcomes of university examination.

The input to the model in Fig. 6 is the course attainments obtained from all internal assessment tools. The model predicts the course attainment of university exam by taking into consideration the trend of course outcome attainment of internal assessment tools and university result. This prediction model gives true reflection in course outcome attainment. Justification Suppose for a particular course there are five course outcomes. Attainment of these course 
outcomes through various tools of internal attainment are at level 3, 3,2,2,1. This indicate student understood and able to solve questions related to first and second outcomes almost $100 \%$. He / She is able to solve questions related to outcomes third and fourth at level 2 means $66 \%$ and question related to fifth outcome is level 1 means $33 \%$. In general students understanding level of COs get reflected in internal attainment. With the help of these data we can predict attainment levels of COs through university question paper by applying above weightage $(100 \%, 66 \%, 33 \%)$.

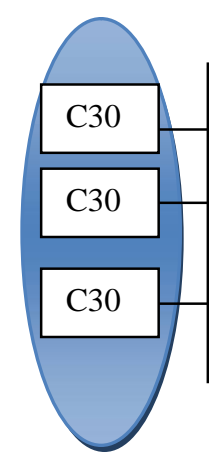

Input: Attainment of Course Outcome through Internal

\begin{abstract}
Output: Predicated Course Outcome of University Exam
\end{abstract}

Fig.6 Predicated University Course outcome through Internal Assessment Course outcome.

2) POs attainment at Course Level: Using the $\mathrm{CO}$ attainment and following the procedure of model 1, attainment of each program outcome can be computed for individual

3) POs attainment at Program Level: Using the $\mathrm{CO}$ attainment of all courses and following the procedure of model 2, attainment of each program outcome can be computed from all courses.

\section{Conclusion}

The paper presents two different models for mapping and attainment of COs and POs. Varies issues related to mapping, setting target levels, identifying courses leading to weak PO mapping as well as the issue of university examination course attainment are discussed in the paper and solution to issues are also proposed.

\section{References}

Mehdi, Riyadh A. K.; AbouNaaj, Mahmoud S. (2013) Academic Program Assessment: A Case Study of a Pragmatic Approach, Creative Education Vol.4, No.1, 7181

Ashley Kranov, Michael Milligan, Joe Sussman.(2011) Dispelling Myths: Common Misconception about ABET and Accreditation, ABET Annual Conference
Amy Driscoll and Swarup Wood. (2007)Developing Outcomes-based Assessment for Learnercentric Education, Stylus Publishing, Sterling, Virginia

NBA website PPT on Outcome Based Education and Accreditation - Awareness Workshop for Evaluators and stakeholders; http://www.nbaind.org/En/1027-formsandformats.aspx

Gloria Rogers, ABET (2010) Webinar on Defining Student Outcomes, www.abet.org

ABET Computing Accreditation Commission (2010). Criteria for ac-crediting computing programs.

National board of accreditation self-assessment report(SAR) (From 1st June, 2015).

Prof.DattaDandge*, Prof.Dr.Suhasini Desai Rubrics: an effective assessment tool for outcome-based accreditation 